\title{
Oral Tradition and the Tourism Village Development
}

\author{
Fitri Alfarisy, Maharani Patria Ratna, Girindra Putri A. R.i, Pradita Dwi A.W. ${ }^{1}$ \\ Applied Foreign Language Study Program, UNDIP, Semarang, Indonesia
}

\begin{abstract}
Oral tradition as the first and the most widespread mode of human communication maintain society and their institution. Numerous studies illustrated that the oral tradition remains the dominant mode of communication in the 21 century. It shared unique characteristics across time and space. It produces a million not-written stories. A place that belongs to home for stories is interesting for the tourist. It means that more stories in the tourism village more tourists come. Therefore, this study will discuss the relation between oral tradition and tourism village development. Observation, document analysis, and depth-interview methods were used to collect data. Kandri tourism village in Semarang was the sample of the study. The results showed that Kandri tourism village has several myths, stories, and traditions taken from the oral tradition. Those traditions and stories attract more tourists to visit. Therefore, we concluded that the oral tradition and the tourism village development have a strong bond in developing their village tourism in maintaining their society, environment, and economy.
\end{abstract}

\section{Introduction}

Oral tradition is also called orality, the first and still most widespread mode of human communication. Far more than just talking, oral tradition refers to a dynamic and highly diverse oral-aural medium for evolving, storing, and transmitting knowledge, art, and ideas. It is typically contrasted with literacy, with which it can and does interact in myriad ways, dwarfs in size, diversity, and social function. [1]

Oral tradition represents a vital and multifunctional means of verbal communication that supports diverse activities in diverse cultures. As the first mode of communication, it bears a striking resemblance to one of the newest communication technologies, the Internet. Both the Internet and oral tradition operate via navigation through webs of options, depending upon multiple, distributed authorship, work through rule-governed processes rather than fossilized texts, and ultimately derive their strength from their ability to change and adapt. [1] 
Other people mentioned that oral traditions are transmitted messages from one generation to another orally. The message may be passed down through speech or song and may take the form of folktales and fables, epic histories and narrations, proverbs or sayings, and songs. Oral Traditions make it possible for a society to pass knowledge across generations without writing. They help people make sense of the world and teach children and adults about important aspects of their culture. [2]

Oral tradition is the heritage of local knowledge, wisdom, and philosophy of life. It can be discovered in folklore, rituals, proverbs, myths, beliefs, performances, and ceremonies. In Indonesia, the oral tradition full of identity and cultural values [3].The oral tradition must be maintained and preserved because it is not merely culture, but national identity. Oral tradition and tourism village inseparable as it is one of the tourist attractions. It attracts visitors to experience cultural value as well as developing the tourism sector.

As we know, tourism has grown in recent decades and is now widely recognized as one of the largest industries in the world. In line with the fact, tourism has boomed in Indonesia in recent years and is one of the main sources of foreign currency earnings. In 2017, the contribution of tourism to GDP amounted to IDR 536.8 trillion, $4.1 \%$ of Indonesia's total GDP. In the same year, tourism provided 12.7 million jobs, representing $10.5 \%$ of total employment. Tourism receipts totaled IDR 200 billion and the sector outperformed the general growth of the Indonesian economy. [4]

In 2018, international arrivals reached 15.8 million, an increase of $12.6 \%$ compared to the previous year. China was the country's main international source market $(16 \%$ of tourists), followed by Singapore (13.2\%), Malaysia (10.6\%), and Australia (9.7\%) [9]. The average length of stay was 8.6 days. In 2017, domestic tourism reached 270.8 million trips growing $2.4 \%$ over the previous year. In 2018, these numbers increased to 303.4 million trips, growing a significant $12 \%$. In some sense, tourism can be a part of the revitalization and preservation of cultural heritage. Tourism may trigger the increase in the creativity of artists, the social and cultural development of society. The increase in tourism certainly improves the economic income of the [5]. Kandri is one of the tourism villages in Semarang that full of products of oral traditions. Many people visit the village to enjoy the culture as well as to see the oral tradition in the form of traditional ceremonies, rituals, and beliefs. Therefore, it is interesting to see the relation between oral tradition and tourism village development to explore the opportunity for developing the tourism village. This paper is aimed to see the relationship between oral tradition and tourism development and to see the sample of the oral tradition as tourist attractions.

1.1. Oral Tradition

Oral traditions are messages that are transmitted orally from one generation to another. The messages may be passed down through speech or song and may take the form of folktales and fables, epic histories and narrations, proverbs or sayings, and songs. Oral Traditions make it possible for a society to pass knowledge across generations without writing. They help people make sense of the world and are used to teach children and adults about important aspects of their culture.

On the other hand, oral tradition is a medium for transferring values, norms, and laws from one individual to another or from one person to another and generation to generation. Vansina [6] said that oral tradition is a verbal message or speech that is conveyed from generation to generation orally, spoken, sung, and conveyed by using musical instruments in a performance that contains verbal and nonverbally transmission. James Danandjaja [7] defined folklore as a part of a culture that spread and passed down from generation to generation in a traditional way, among any collective members in Indonesia, in different 
versions, either in oral form or in the form of examples accompanied by actions and reminder tools, mnemonic devices.

Ong [8] mentioned that the development of oral culture including primary oral and secondary oral. Primary orality refers to the oral culture which completely untouched by writing and printing. In other words, it is called basic oral for a culture that has never known writing. Memory becomes very important and is highly valued and cultivated. Ong [8] formulates the effort to remember as think memorable thoughts (to be easy to remember). By the times, people started to know the written culture, so every single piece of verbal information was written well. Even though it has become a manuscript, it can still be sung, said, performed, and transmitted orally. Oral traditions no longer appear when the speaker meets directly with the audience at the same time and place, but appear in the form of video or voice recordings that can be played any time.

\subsection{Tourism Village}

Tourism becomes a major commodity for Indonesian to increase economic growth and introduce culture both in urban and rural areas [9]. The tourists usually choose tourist destinations related to nature by promoting culture and local wisdom and can entertain them while educating them such as hiking, trekking, cultural tourism, and tourist villages [10]. Tourism village is a new alternative destination developed by the government and community to improve community welfare. On the other hand, the construction of tourism villages is also to preserve the environment and to elevate the local potential based on local wisdom [11].

The destinations are built to improve local communities' finance and local governments as well as providing a new atmosphere for local and foreign tourists [9]. One government program is to develop potential in the tourism sector which is a service sector that can rapidly develop and can generate foreign exchange for the country [12]. The development of modern tourist destinations needs to be carefully planned such as providing supporting facilities both by the local government, the surrounding community, and other stakeholders so that they can become a source of power and attractiveness which in turn is in great demand by tourists [13]. Tourism businesses must also be able to evaluate the strengths and weaknesses of the construction of tourist villages so that competitiveness can be known from the regions they developed for a long period in the tourism market [9].

Development of village tourism or tour village is also considered to have the ability to minimize the potential urbanization of society from rural to urban areas because it can create economic activity in rural areas based on tourism activities. [14] The productive potential of local potentials including those of rural potentials can be encouraged to grow and develop through the utilization of village-owned resources so that it can be an effective instrument in fostering the socio-cultural and economic development of rural communities. Furthermore, it will be encouraged by various efforts to preserve and empower the potential of unique local culture and local wisdom values that are likely to be threatened with extinction due to the intensified globalization and rural entry into the countryside. Village tourism is based on the potential utilization of the village with all the community entities, nature, and culture that exists in it as the power of tour attraction [15]. Kandri village tourism itself is one of the best tourism villages in Indonesia. They promote the culture as well as the value of the village. The number of oral traditions in the village showed that how the village preserves its beliefs and promotes them as one of the tourist attractions. 


\section{Methods}

This research used in-depth interviews to collect the data about the relation of the oral tradition and tourism village development as well as the sample of the oral tradition. An in-depth interview is part of qualitative methods that offer the opportunity to capture rich, descriptive data about how people think, behave, and unfolding complex processes. The interview is conducted by using a discussion guide which facilitates the respondent's views through open-ended questioning. These interviews were held with the members of Kandri tourism management. The results of the interviews were presented in the results of the study.

\section{Results and Discussion}

Tourism becomes a major commodity for Indonesian to increase economic growth and introduce culture both in urban and rural areas [9]. The tourists usually choose tourist destinations related to nature by promoting culture and local wisdom and can entertain them while educating them such as hiking, trekking, cultural tourism, and tourist villages [10]. Tourism villages usually perfomed several ceremony or rituals as the products of oral traditions. Kandri Tourism Village, one of village in Semarang, Central Java have many oral traditions that preserved and promote as tourist destinations [16]. Based on the interviews with tourism village management, the oral tradition and tourism development has strong bounding. They mentioned that many stories about Kandri tourism village is transferred orally. Those stories related to the history of the Kandri village, the information about Water Springs and the rituals. Here are the oral tradition that found in the Kandri Tourism Village.

\subsection{The Legend and Origin of Kandri Village}

The Kandri is related to Selo Purwodadi Village, Grobogan Regency. A long time ago, two siblings of Islamic students came from Selo Village named Sariah Alhafidloh and Sariani. They came from the place which was known as Kyai Ageng Selo (Lightning Catcher) Tomb. They traveled into Semarang and stop by Kandri Village. They saw many Kandri trees, then named it Kandri Village (KH. Muhaiminan Gunardo, the Head of Bamboo Runcing Parakan Islamic Boarding School, Temanggung). Then, both of them stay in Kandri. Sariani is known as Mbah Pacul and was buried at Talun Kacang RW 03 Cemetery. On the other side, Mbah Nyai Sariyah was burried at Dusun Kandri RW 1 Kelurahan Kandri Cemetery.

\subsection{Springs in Kandri Village}

Kandri is well-known for its springs, and each of them has its benefits.

\subsubsection{Gede Water Spring}

There was a huge water source in Gede Water Spring, but the Kandri people worried that the flood comes, and then change their land to become a swamp. Then, they try to block it with a gong, a buffalo head, and a jadah. However, the water still flows from the water source, so they use it to create a spring known as Sendang Gede.

The Water Spring has plenteous water for people, a watering rice field, and fish ponds. They depend on the spring until now. The water also has efficacy for help the woman to 
feel beautiful. The uniqueness of the Water Spring is that the water sometimes changes to clear, blue, and blood-red colors.

By being gifted by Allah SWT, Kandri village held Nyadran Kali every Thursday Kliwon of Jumadil Akhir. It was a cultural activity as shown their gratitude. They had given plenteous water for daily life and agriculture. The Nyadran procession Kali starts with villagers march carrying the head of the buffalo, gong, and jadah following by women bringing rice in baskets and banana leaves for eating together in the spring area.

\subsubsection{Prohibitions in Gede Water Spring}

1. Visitors must not make fun of the water or other things found in the Water Spring.

2. Visitors are not allowed to wash housewares/cooking tools in the Water Spring.

3. If visitors are joking, they should not make anyone cry. If someone is crying, they should come out of the Water Spring or take them home.

4. Visitors must ask permission from a caretaker (Mr. Kyai Ahmad Supriyadi) or his representative before taking the water to the house.

5. If visitors see anything that seems strange, they should not bother or ignore it.

\subsubsection{Jambu/Jamu Water Spring}

At the inception of this water spring, it started at a cluster fig tree. The tree is perceived to be unique by the locals. Without any flower visible to pollinate itself, yet bears fruit in the shape of guava. Hence the name Jambu (guava) water spring. The locals also believe the water has the efficacy to cure all kinds of diseases. There was a story about a person who has been ill for a long time, and then he recovers after showering in the water spring at midnight. Due to its benefits, some locals refer to this place as Jamu (herbal medicine) water spring. The water can adjust the person who uses it according to what they need. If their body feels cold while taking a shower, the water will feel warm. Likewise, if their body feels warm, the water will feel cold. Until now, people come for their treatment by bathing in the water spring every Kliwon Monday night and Kliwon Thursday night. Directions at Jambu/Jamu Water Spring:

1. If visitors take a bath in the Water Spring to cure diseases, they should bath after midnight before other people touch the water. They should contact the caretaker (Mr. Kyai Ahmad Supriyadi) or his representative beforehand.

2. If visitors see anything that seems strange, they should not bother or ignore it.

\subsubsection{Pancuran Water Spring}

Why is it called Pancuran water spring? People call it Pancuran water spring as water flowed by an iron pipe for bathing and washing. This water spring has the efficacy to cure all kinds of diseases if it is taken directly from the water source. The strange thing about the water spring is that water will disappear if taken directly from the water source, meaning that the guardian spirit is angry. Moreover, only the caretaker can restore it to normal.

\subsubsection{Gawe Water Spring}

Gawe Water Spring has efficacy for people who will do activities or work even looking for a job. When someone is looking for a job, they will bathe in the water spring. With Allah's will, they will get the job as soon as possible. Some water-springs no more used in Kandri Village includes Munggur, Nongko, Getas, and Siwuni water springs. 


\subsection{Kandri Tourism Village Annual Events}

\subsubsection{Sesaji Rewandha}

Sesaji Rewandha on 3rd Shawwal (the third day of Eid al-Fitr) known as feeding monkeys (Rewandha) as guardians of Goa Kreo ceremony. It begins with the traditional ritual by bringing the offerings and replicas of Kanjeng Sunan Kalijaga inheritances. It is followed by sacred dances, cutting cones, and sharing cones (contested) by visitors. It ends by feeding the long-tailed monkeys.

\subsubsection{Nyadran Sendang}

Nyadran Sendang every Thursday Kliwon in Late Jumadil Akhir is preceded by cleaning the springs in Kandri (Sendang Gede, Guava Sendang, Kidang Sendang). It is followed by the carnival of Nyadran Sendang Properties like Gong Replica, Bamboo Head Replica, various kinds of Gunungan, and other properties. It is accompanied by all villagers bringing many offerings.

\subsubsection{Nyadran Kubur}

Nyadran Kubur every Tuesday Pon Rajab is a procession of sending dua to their families at the Tomb or Sarean Siwarak Village. It continued with the Local Carnival of Arts and Culture like handicraft products, souvenirs, souvenirs, various kinds of snacks, culinary, and many more exhibitions. The main event is the Babat Tanah Siwarak Opera performance, which told the history of Siwarak Village covered by the Islamic Pengajian Akbar.

\section{Conclusion}

Oral traditions are transmitted messages orally from one generation to another in the form of folktales and fables, epic histories and narrations, proverbs or sayings, and songs. Those oral traditions preserve by Kandri villagers foster their village to be one of the best tourist villages in Indonesia. Mr. Edi, as a manager, mentioned that through those ceremonies and beliefs about the water springs, they are not only tried to preserve the value but also attract the visitors to come and enjoy the place. The visitors come to the village to enjoy the environment and story at the same time. The oral tradition exploration potential can be encouraged to grow and develop through the utilization of village-owned resources, pushing socio-cultural and economic development. It will also enhance the visitors and the villagers to preserve and empower the potential of unique local culture and local wisdom values that are likely to be threatened with extinction due to the intensified globalization. 


\section{References}

[1] Achadiati. "Beraksara dalam Kelisanan" in Metodologi Kajian Tradisi Lisan. ATL. Jakarta (2008)

[2] World Affairs Council of Houston. The Oral Traditions of Africa. https://static1.squarespace.com/static/53cfd0e5e4b057663ea1bc61/t/57b1e0b746c3 c406dd172afd/1471275383444/Oral+Traditions + of + West + Africa.pdf

[3] Y. Supriatin. OLaNI: TCSoIVSR. Pat. J. 4, 3, 407-418 (2012)

[4] OECD Lib. ITITE. https://www.oecd-ilibrary.org/sites/6c4fc1cden/index.html?itemId=/content/component/6c4fc1cd-en (2018)

[5] T Dewi. "Dewi Sri sebagai Mitos Kesuburan dan Realitanya dalam Masyarakat Jawa" in Pujiastuti, Titik \& Tommy Christomy. Teks, Naskah, dan Kelisanan Nusantara. YPN, Depok (2011)

[6] J. Foley. OTC, https://www.britannica.com/topic/oral-tradition (2019)

[7] J. Vansina. Oral Tradition as History. JCP. Oxford (1985)

[8] W. Ong. Orality and Literacy: The Technologizing of the Word. London and New York, (1982)

[9] D. Leonandri, and M. TRTVtILCIR. BIRCI-J, I, 4, 188-193 (2018)

[10] S. Chutia. 2015. "PaPoTIiA" Int. J.O.I. R.i.S.E.a.T, 4, 2, 633-638, (2015)

[11] S. Pike and C. Ryan. 2004. "DPAtaCoCAaCP", J.o.T.R, 42, 4, 333-342, (2004)

[12] W. Semasinghe. "IToP-WSDCaO", Int J. E. C.M, IV, 6, 1-18, (2016)

[13]B.J.R. Ritchie and G.I. Crouch. "TCD: ASP," Tour Manag. J, 21, 2, 1-7 (2000)

[14] A. Hamzah and M. Irfan. LECCD No. 69/PUU-XII/2015. Not. J, 3, 1, 01 - 12 (2018)

[15] J. Danandjaja. "Pendekatan Folklore dalam Penelitian Bahan-Bahan Tradisi Lisan" in Metodologi Kajian Tradisi Lisan. ATL. Jakarta (2008)

[16] M. P. Ratna, F. Alfarisy, and G. P. A. Reswari, "PBPT TGDW, K, GP, S, Har. JPKM, 4, 2, 52-55, (2020) 